\title{
Apoptotic Potential of Artemsia sieberia Besser (Asteraceae) Fraction against Human Cancer Cell Lines
}

\author{
Nael Abutaha*, Ashraf MA Mashaly, Muhammad Farooq and Muhammad A \\ Wadaan \\ Bioproducts Research Chair, Department of Zoology, College of Science, King Saud University, Saudi Arabia
}

*For correspondence: Email: naelabutaha@yahoo.com; Tel: +96591912845

Received: 24 March 2015

Revised accepted: 29 August 2015

\begin{abstract}
Purpose: To investigate the anti-proliferative and apoptotic activity of crude and dichloromethane fraction of A. sieberi against seven cancer cell lines (Colo20, HCT116, DLD, MCF7, Jurkat, HepG2 and L929).

Methods: A. sieberi was extracted with methanol and further purification was carried out using liquidliquid extraction with hexane, dichloromethane and ethyl acetate. Each extract was assayed for cytotoxic potential against cancer cell lines using 3-(4,5-dimethylthiazol-2-yl)-2,5-diphenyltetrazolium Bromide (MTT) assay. The morphology of the HepG2 cell nucleus was investigated by Hoechst 33342, DNA-binding dye. A TalitM image-based cytometer was used to assess cell viability, death and apoptosis using annexin-v/pi (propidium iodide). A chromatographic fingerprint was constructed using high performance liquid chromatography (HPLC).

Results: The most effective anticancer activity of the unrefined methanol extract was against HepG2 cell lines $\left(L C_{50}=161.5 \mu \mathrm{g} / \mathrm{mL}\right)$. The hexane and ethyl acetate fractions showed no antiproliferative activity. The dichloromethane fraction displayed higher cytotoxic activity $\left(L C_{50}=61.75 \mu \mathrm{g} / \mathrm{mL}\right)$ and also repressed the migration of the cells. About $50 \%$ of HepG2 cells were apoptotic when treated for $24 \mathrm{~h}$ with the dichloromethane fraction at the concentration of $120 \mu \mathrm{g} / \mathrm{mL}$

Conclusion: A. sieberi possesses apoptotic activity and inhibited the migration of the HepG2 cell lines.
\end{abstract}

Keywords: Artemsia Sieberia, Apoptosiss, Cytotoxicity, Hoescht staining, HepG2 cell lines

Tropical Journal of Pharmaceutical Research is indexed by Science Citation Index (SciSearch), Scopus, International Pharmaceutical Abstract, Chemical Abstracts, Embase, Index Copernicus, EBSCO, African Index Medicus, JournalSeek, Journal Citation Reports/Science Edition, Directory of Open Access Journals (DOAJ), African Journal Online, Bioline International, Open-J-Gate and Pharmacy Abstracts

\section{INTRODUCTION}

Plants are considered to be among the main natural sources of bioactive chemicals. Millions of people believe in the use of plant and herbal remedies for almost all ailments [1]. Around 50 $\%$ of the prescriptions in the USA and Europe are of natural origin or derived from natural sources [2]. In the Middle East region around 700 species of known plants are known for their medicinal properties [3].
The main factor which contributes to the failure of many forms of chemotherapy is drug resistance [4]. This resistance means that it is important to look for new anticancer agents to bypass the resistance mechanisms. Synthetic chemistry has traditionally been believed to be the dominant method for drug discovery, but using plants with medicinal value as a source for unique natural products for treatment and disease prevention is an increasingly promising route [4].

Artemisia is an extensively distributed genus of the Asteraceae family. A. sieberi is a widely 
distributed perennial shrub in the Middle East and Mediterranean regions [6]. Among the plants that have been studied in Jordan, $A$. sieberi is recorded to have the highest use value. In Jordan, the locals Bedouins traditionally used it for the treatment of heart disorders, sexual weakness in males, diabetes, stomach ache [7] and for the treatment of wounds [8]. In Saudi Arabia, Bedouins inhale the smoke produced by burning this plant for unspecified medicinal properties [9]. A. sieberi has anti-bacterial, antioxidant, neurological, anti-spasmodic, pesticidal, hypoglycemic and cytotoxic activities. [5].

In this article, we partially purified the unrefined extract of the aerial parts of $A$. sieberi using a bioassay-guided procedure to explore the anticancer potential of the unrefined extract and the fractions obtained against seven cancer cells lines.

\section{EXPERIMENTAL}

\section{Plant material}

The aerial parts of $A$. sieberia were collected from Wadi Hanifa, Riyadh, Kingdom of Saudi Arabia, in January 2014. The Identity of the plant was authenticated in the Department of Botany and Microbiology, College of Science, King Saud University, where the specimen was deposited (voucher no:132014). $100 \mathrm{~g}$ of the aerial parts were blended in a Waring blender with $500 \mathrm{~mL}$ methanol and left to stir overnight at $150 \mathrm{rpm}$ and $30{ }^{\circ} \mathrm{C}$. This process was repeated three times, adding fresh methanol to the remaining residue on each occasion. The extract was pooled and centrifuged for $10 \mathrm{~min}$ at $5000 \mathrm{rpm}$. The supernatant was pooled, dried at $45^{\circ} \mathrm{C}$ using a rotary evaporator and kept in the freezer until use.

\section{Partial purification of the unrefined methanol extract by partition in solvents of different polarities}

The unrefined methanol extract of $A$. sieberia was dissolved in $20 \%(\mathrm{v} / \mathrm{v})$ methanol and then a similar amount of hexane was added and stirred for $5 \mathrm{~min}$. The hexane layer containing the nonpolar compounds was collected. This process was repeated twice and the hexane layers were pooled and combined, and later evaporated in a rotary evaporator at $45^{\circ} \mathrm{C}$. The methanol phase was then mixed with a similar volume of dichloromethane and the same process was repeated as per hexane above. The process was repeated with ethyl acetate following the same procedure. The fractions were dissolved in methanol and used for the tests.

\section{Proliferation and cytotoxicity assays}

The seven cancer cell lines selected for the in vitro antiproliferative bioactivity screening were Colo20, HCT116, DLD (colorectal adenocarcinoma). MCF7 (human breast cancer), Jurkat (human T lymphocyte), HepG2 (hepatocarcinoma) and L929 (mouse fibrosarcoma cells). The cells were grown in Dulbecco's modified Eagle's medium (DMEM) complemented with $10 \%$ foetal bovine serum in standard 24 well-plates. In each well the cell suspension ( $1 \mathrm{~mL}, 10^{5}$ cells $/ \mathrm{mL}$ ) was incubated at $37^{\circ} \mathrm{C}$ for $24 \mathrm{~h}$ in $5 \% \mathrm{CO}_{2}$. Extracts were studied for cytotoxic activity using the 3-(4, 5-dimethylthiazol-2-yl)-2, 5-diphenyltetrazolium bromide (MTT) test. After $24 \mathrm{~h}$ of treatment, the culture medium was aspirated and fresh DMEM medium containing MTT $(0.1 \mathrm{mg} / \mathrm{mL})$ was added. After $2 \mathrm{~h}$ of incubation, this solution was aspirated, and the blue formazan formed was dissolved in $100 \mu \mathrm{L}$ of $0.1 \% \mathrm{HCl}-\mathrm{MeOH}$. The plates were read at $595 \mathrm{~nm}$ using a micro plate reader (Biochem Ltd, England).

\section{Hoescht 33258 staining}

Evaluation of morphological of apoptosis was assessed by Hoechst 33258 dye. The cells were plated in 6-well tissue culture plates $\left(5 \times 10^{4}\right.$ cell $/ \mathrm{mL}, 1 \mathrm{~mL} /$ well) and following incubation overnight, the old medium was substituted with fresh medium. The culture medium containing the dichloromethane fraction was aspirated, and the cells were fixed in $3 \%$ paraformaldehyde for $20 \mathrm{~min}$. Cells were washed twice with phosphate buffer saline (PBS), and subsequently stained with $0.1 \mu \mathrm{g} / \mathrm{mL}$ of Hoechst 33258 dye (Life Technology, USA) for 15 min in the dark. The stained cells were rinsed five times with PBS, and were then observed under a fluorescent microscope at 340-380 $\mathrm{nm}$ emissions [10].

\section{Tali ${ }^{\mathrm{TM}}$ analysis}

The cells were seeded in a T25 flask and incubated with the dichloromethane fraction at a concentration of $95 \mu \mathrm{g} / \mathrm{mL}$. $24 \mathrm{~h}$ post-treatment, the cells were trypsinized, harvested and stained using annexin-V Alexa Fluor ${ }^{\circledR}$ 488/PI (propidium iodide), according to the kit instructions (Tali ${ }^{\mathrm{TM}}$ apoptosis kit, Invitrogen). Cell death, viability and apoptosis were examined using the Tali ${ }^{\mathrm{TM}}$ Image-based Cytometer (Life Technologies). The experiments were performed in triplicate. 


\section{Wound healing assay}

The cells were seeded in plastic 6-well plates until they reach confluence. Cells were scratchwounded with the aid of a sterile tip and treated with the dichloromethane fraction. The cells were photographed after $24 \mathrm{~h}$ of incubation using phase-contrast microscopy.

\section{HPLC analysis}

The sample was filtered through $0.2 \mu \mathrm{m}$ polyvinylidene difluoride (PVDF) filter (Millipore) to remove any particulate matter. Analysis was achieved using a HPLC (PerkinElmer) equipped with ultraviolet-visible detectors. $10 \mu \mathrm{L}$ of the sample was injected and analyzed. The column used was $\mathrm{C} 18(250 \times 4.6 \mathrm{~mm})$ at a room temperature $\left(25^{\circ} \mathrm{C}\right)$. The analysis was performed in a gradient system using a mixture of acetonitrile: water containing $0.5 \%$ acetic acid as an eluent.

The gradient program is depicted as shown in Table 1.

Table 1: The gradient programme of the HPLC mobile phase for profiling the dichloromethane fraction

\begin{tabular}{cccccc}
\hline Step & $\begin{array}{c}\text { Time } \\
(\mathbf{m i n})\end{array}$ & $\begin{array}{c}\text { Flow } \\
(\mathbf{m l} / \mathbf{m i n})\end{array}$ & $\begin{array}{c}\text { Solvent } \\
\text { A }\end{array}$ & $\begin{array}{c}\text { Solvent } \\
\text { B }\end{array}$ & Curve \\
\hline 0 & 5 & 0.5 & 70 & 30 & 0 \\
1 & 10 & 1 & 70 & 30 & 0 \\
2 & 10 & 1 & 30 & 70 & 1 \\
3 & 5 & 1 & 0 & 100 & 0 \\
\hline
\end{tabular}

\section{RESULTS}

The cytotoxicity of the unrefined methanolic extract of Artemsia sieberia was examined in respect to Colo20, HCT116, DLD, MCF7, HepG2, Jurkat, and L929 cell lines, whereas the dichloromethane fraction was tested on just the MCF7 and HepG2 cell line. Initially, different concentrations of the unrefined methanolic extract of $A$. sieberia were used for the treatment of the seven cancer cell lines (between 50-500 $\mu \mathrm{g} / \mathrm{mL}$ ). The $\mathrm{LC}_{50}$ values of the methanolic extract of $A$. sieberia against Colo20, HCT116, MCF7, Jurkat, HepG2, and L929 were 339.36, $397.76,333.01,321.88,161.50$, and 322.73 $\mu \mathrm{g} / \mathrm{mL}$ respectively (Figure 1 ). The extract was less effective against the DLD cell line, however with the highest concentration demonstrating an inhibition of just $57.99 \%$ inhibition. The most effective anticancer activity of the unrefined methanol extract was against HepG2 cell lines, which exhibited an $\mathrm{LC}_{50}$ value of $161.50 \mu \mathrm{g} / \mathrm{mL}$.

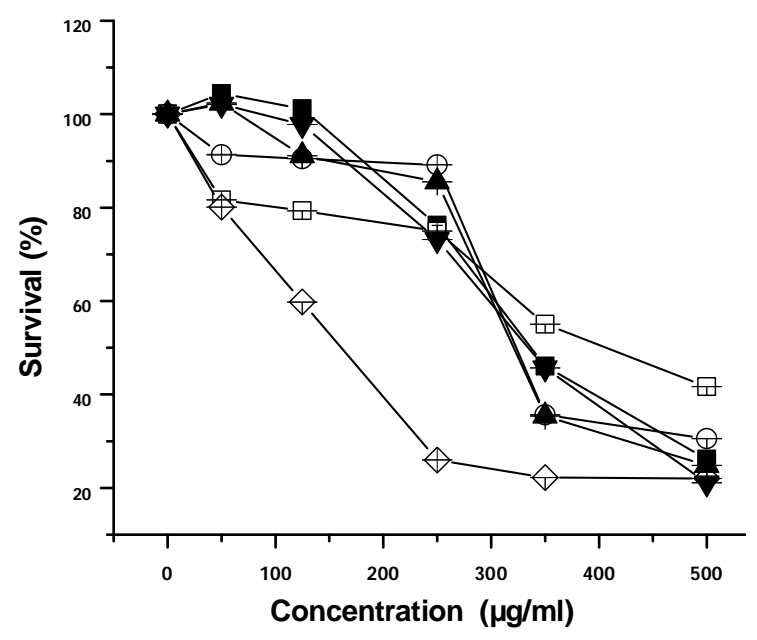

Figure.1: Cytotoxicity of crude methanol extract on different cancer cell lines. Values are mean $\pm S D(n=$ 3). - COLO 20, $\square$ HCTT 116, $\Delta$ L929, $\diamond$ HEPG2, $\nabla$ MCF7, ○ JURKAT

To compare the cytotoxicity of the obtained fractions of $A$. sieberia aerial part extract, different concentrations ranged between 10-200 $\mu \mathrm{g} / \mathrm{mL}$ were used. The hexane and ethyl acetate fraction showed no antiproliferative activity but, the dichloromethane fraction exhibited the most antiproliferative effects on HepG2 and MCF7 cell lines. The $\mathrm{IC}_{50}$ values of this fraction against the HepG2 and MCF7 cell lines, after $24 \mathrm{~h}$, were 61.75 and $139.39 \mu \mathrm{g} / \mathrm{mL}$ respectively (Figure 2). The proliferation of cell lines tested for the unrefined methanolic extract and the partially purified dichloromethane fraction were found to be reduced in a dose dependent manner.

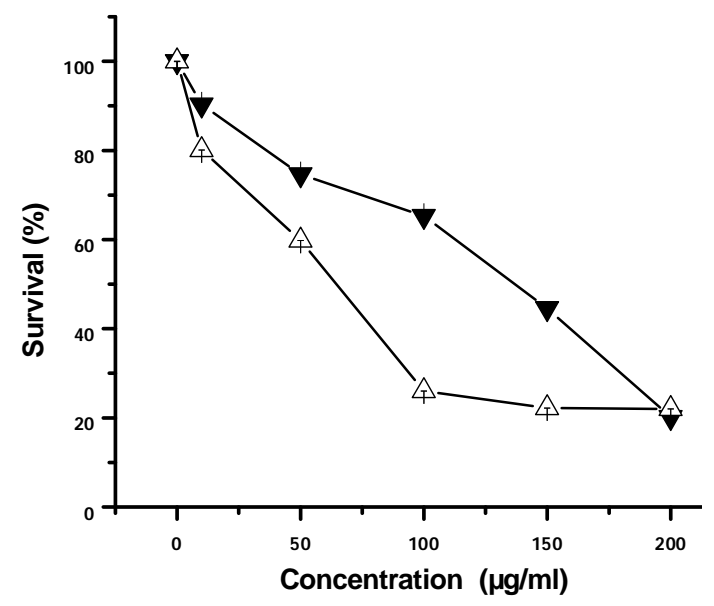

Figure 2: Antiproliferative effect of the dichloromethane fraction on HepG2 and MCF7 cell lines after $24 \mathrm{~h}$ of incubation. Values are mean \pm SD ( $\mathrm{n}$ = 3). $\nabla$ MCF7, $\triangle$ HEPG2 
In this study, assessment of apoptosis was performed by assessment of morphological and nuclear, changes as well as by Annexin V/PI double parameter assay were conducted. The morphology of the HepG2 cells was changed whereas the control cells were of normal cellular morphologies. Detachment, cellular integrity loss and shrinkage of cytoplasm were all observed in the treated HepG2 cells (data not shown). As shown in Figures 3A and3B, cells treated for $24 \mathrm{~h}$ with the dichloromethane fraction exhibited changes in the chromatin structure including fragmentation, even and even condensation and clustering against the nuclear border (arrowheads, Figure 3B). In contrast, the methanol control (Figure $3 \mathrm{~A}$ ) remained evenly stained with bright fluorescence nuclei.

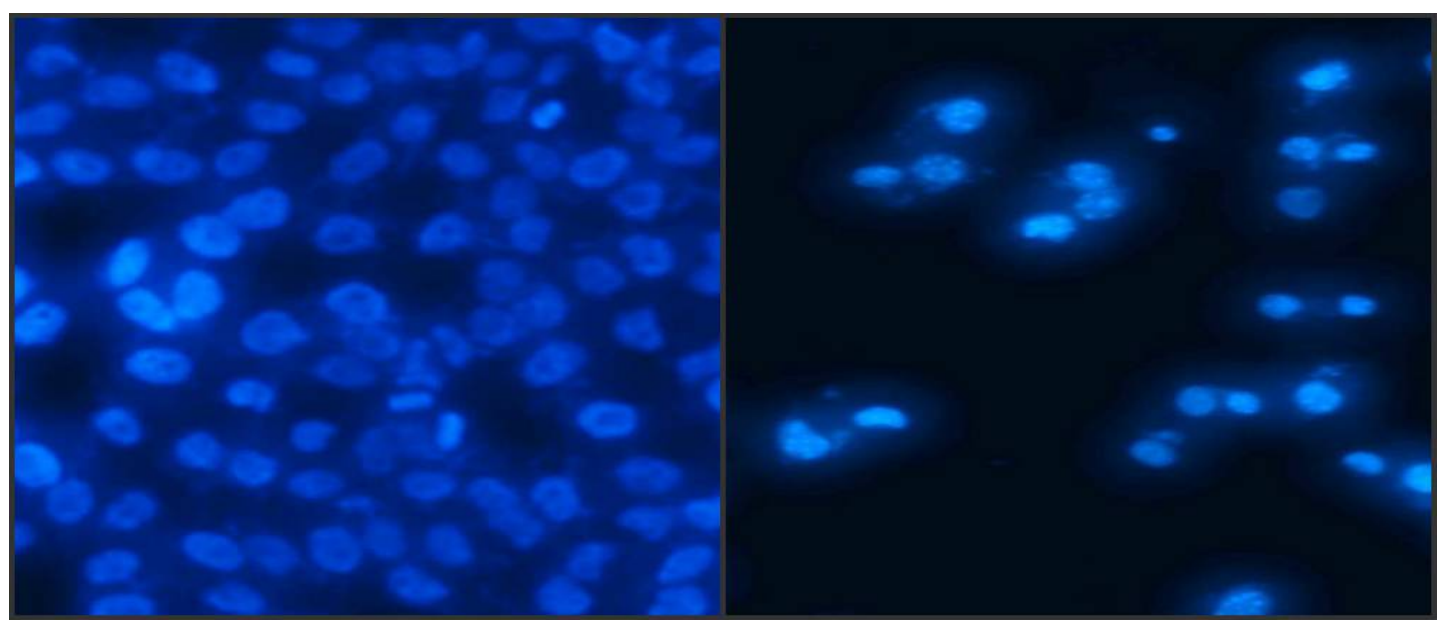

Figure 3: Dichloromethane fraction caused apoptosis in HepG2 cells when stained with Hoechst 33258 and observed at 40X using fluorescence microscope. (A) Control $(0.1 \%$ Methanol) cells; (B) treated cells $(100 \mu \mathrm{g} / \mathrm{mL})$. Apoptotic morphology was confirmed by nuclear condensation, and round apoptotic bodies (white arrows)

Annexin V/PI staining is a sensitive technique for the detection of apoptosis. Cells were incubated with $120 \mu \mathrm{g} / \mathrm{ml}$ of dichloromethane fraction in a T25 flask. They were then harvested and stained using annexin-V/PI (propidium iodide). The cells were considered apoptotic if they were positive for annexin- $V$ and negative for propidium iodide. When the cells were positive for both the annexin $\mathrm{V}$ and propidium iodide, however they were determined to be dead cells. Similarly, when the cells were negative for both the annexin $\mathrm{V}$ and propidium iodide they were identified as viable cells. The treatment of HepG2 cells at concentrations of $120 \mu \mathrm{g} / \mathrm{ml}$ resulted in statistically significant apoptosis which appeared after $24 \mathrm{~h}$ with $49.6 \%$ inhibition using the dichloromethane fraction when compared with untreated cells $(p<0.01)$ (Figure 4$)$.

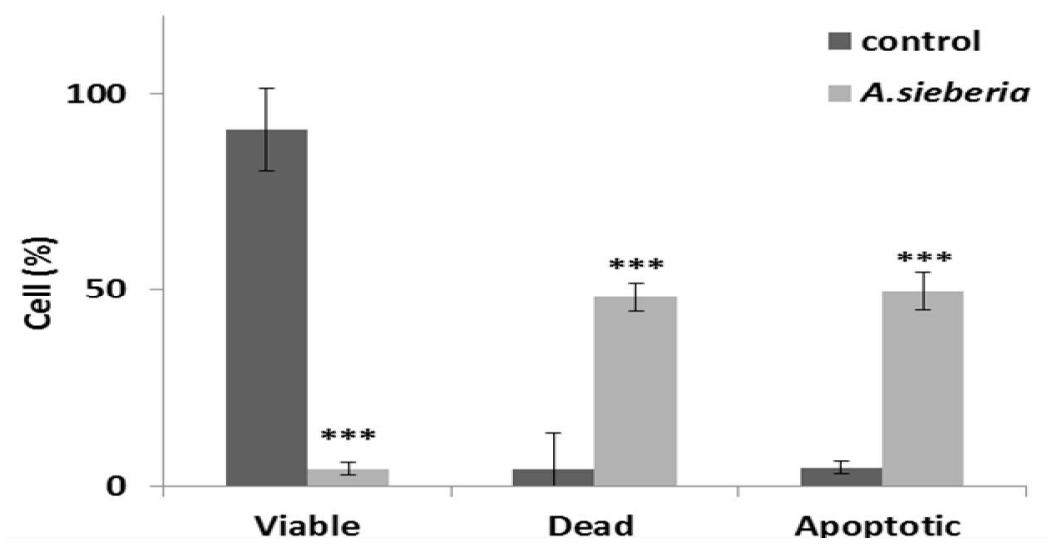

Figure 4: Viable, apoptotic and dead cells after treatment with the dichloromethane fraction at a concentration of $120 \mu \mathrm{g} / \mathrm{mL}$ for $24 \mathrm{~h}$. The results are illustrated as mean $\pm \mathrm{SD}(n=3) ;{ }^{* \star *} P<.001$ in comparison to the untreated control group; ${ }^{* *} p<0.05$ in comparison to the untreated control group 
The wound healing assay investigated the ability of the dichloromethane fraction to suppress the migration of HepG2 cells in a denuded area at a concentration of $100 \mu \mathrm{g} / \mathrm{ml}$ and after incubation for $24 \mathrm{~h}$. A reduction of cell migration was obtained by treatment with the dichloromethane fraction (Figure 5C-5D), while no migration was observed in the control untreated group (Figure $5 A-5 B)$.

HPLC fingerprint (Figure 6) of $A$. sieberia dichloromethane fraction revealed the presence of various constituents as evidenced by the chromatogram obtained at different retention times.

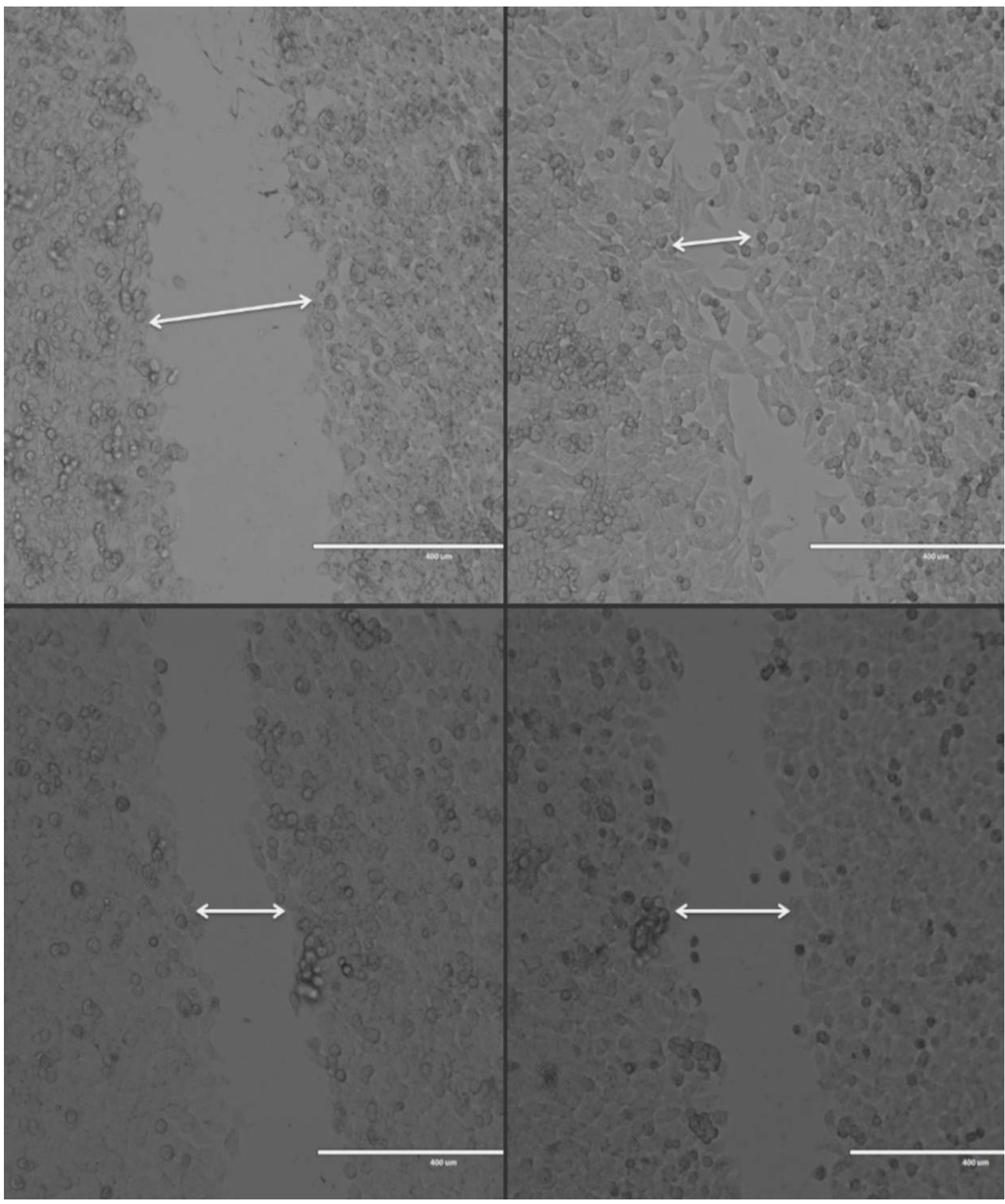

Figure 5: Dichloromethane fraction activity on the migration of HepG2 cells. Cells were scratch-wounded with a sterile tip and incubated with $100 \mu \mathrm{g} / \mathrm{mL}$ for $24 \mathrm{~h}$, in control well $(A, B)$ and the dichloromethane fraction treated well (C.D). The cells were photographed with phase-contrast microscopy using 40x objective 


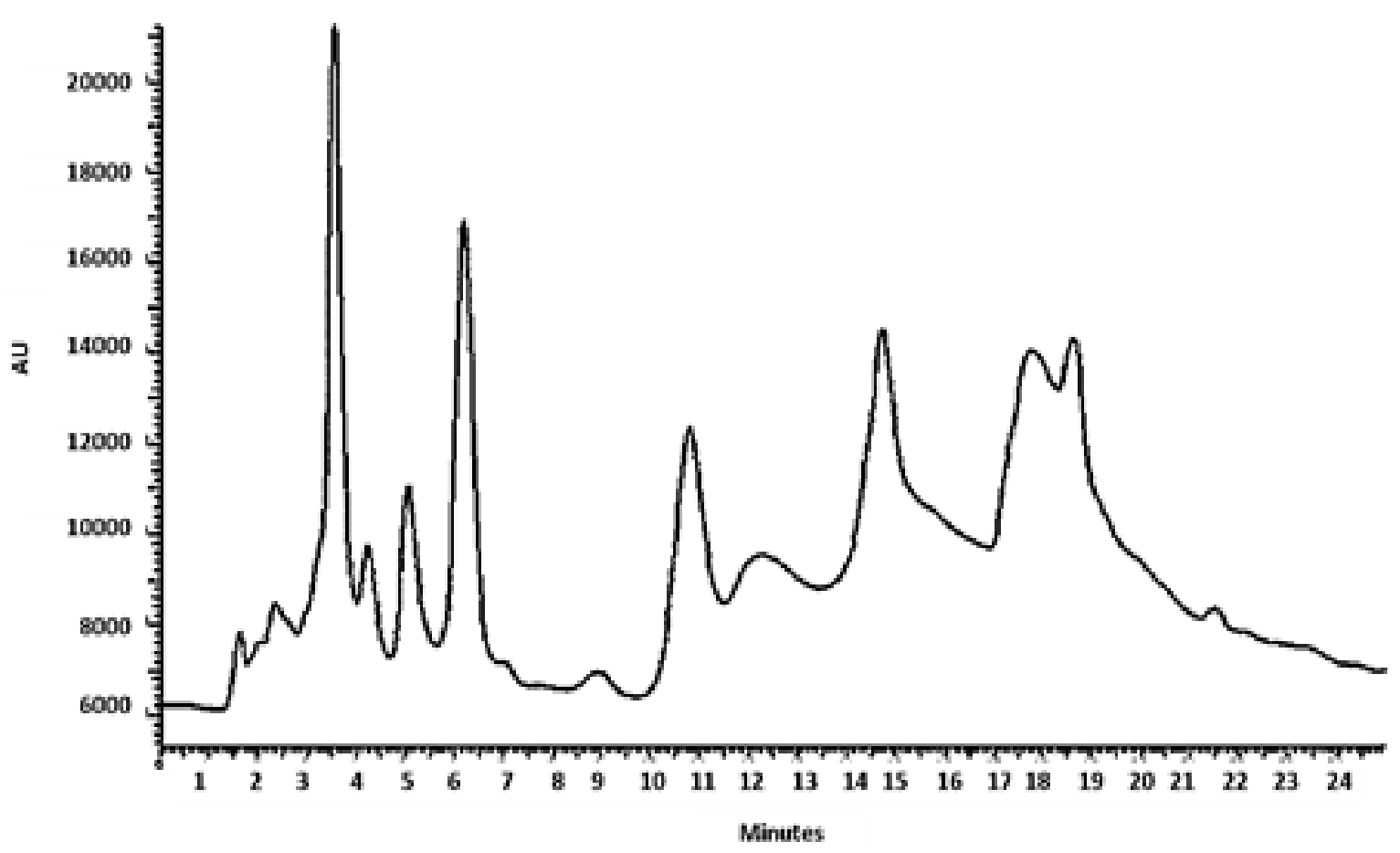

Figure 6: HPLC profile showing the components revealed in the dichloromethane fraction of $A$. sieberia at 254 $\mathrm{nm}$

\section{DISCUSSION}

Although several investigations have been conducted in the control of cancer progression, still significant work is still required to develop and bypass drug resistance to existing drugs. Medicinal plants are a rich source of biological activity and played an indispensable role in cancer chemotherapy such as in the case of Vincristine and Vinblastine alkaloids isolated from Vinca rosea, in addition to Taxol isolated from Taxus brevifolia.

The findings of the present study have revealaed that the unrefined methanolic extract of $A$. sieberia and its dichloromethane fraction affected HepG2 cell morphology dose dependently. The antiproliferative activity exhibited by the dichloromethane fraction can probably be attributed to its moderately polar compounds.

This study was in agreement with the reports published by other researchers who have confirmed the cytotoxicity of the crude extract of $A$. sieberia. It has been reported that the total unrefined alcohol extract obtained from $A$. sieberia shows a potent inhibition against the murine mastocytoma cell line (P815) and the kidney carcinoma cell lines of hamsters (BSR) [11]. While, in another article, $A$. sieberia unrefined extract exhibited dose dependent antiproliferative activity against several cancer cell lines (human bladder carcinoma RT112, human laryngeal carcinoma and human myelogenous leukaemia K562), with $\mathrm{IC}_{50}=$ $81.59,59.05$ and $90.96 \mu \mathrm{g} / \mathrm{mL}$ respectively [12]. The ethanol extract of $A$. sieberia significantly reduced $\mathrm{HCT} 116$ viability $\left(\mathrm{IC}_{50}\right.$ of $51 \mathrm{mg} / \mathrm{mL}$ at 24 h) in a dose dependent manner and induced apoptosis [13].

Induction of apoptosis has been documented as an indication for the development of an anticancer agent [14] because most chemotherapeutic drugs prompt cancer cell death through apoptosis [15]. One of the interesting outcomes of this study was induction of cell death through apoptosis by the dichloromethane fraction. Our results also revealed that the dichloromethane fraction of $A$. sieberia also induced apoptosis when analyzed by Annexin V/PI assay. This result was in accordance with the morphological studies.

Metastasis is one of the key challenges for a successful cancer treatment [16] and the prevention of cancer metastasis is as important target for improving a patient's prognosis. The use of the dichloromethane fraction of $A$. sieberia as a promising anticancer agent is strengthened by the wound healing assay the fraction exhibited against HepG2 cells. 
The HPLC fingerprint of the $A$. sieberia dichloromethane fraction revealed the presence of various constituents, and this profile can be exploited for the purposed of identification, chemical characterization [19] and the quality control of herbal medicines complexity [20]. The HPLC profiles of the dichloromethane fraction of A. sieberia may enable drug companies to adjust the quantity of the fraction and thus help in the preparation of a standardized product. Additional investigations are required to isolate the active principle and explain the molecular mechanisms of dichloromethane fraction of $A$. sieberia in cancer therapy.

\section{CONCLUSION}

The dichloromethane fraction of $A$. sieberia caused cell membrane integrity damage, and initiated an apoptotic response in HepG2 cells. These results suggest that this dichloromethane fraction is a good candidate for the development of new therapies for human cancer.

\section{ACKNOWLEDGEMENT}

The authors extend their appreciation to the Deanship of Scientific Research at King Saud University for funding the work through the research group project no. RGPVPP- 028.

\section{REFERENCES}

1. Ghazanfar SA. Handbook of Arabian medicinal plants: CRC Press; 1994.

2. Verpoorte R. Pharmacognosy in the new millennium: leadfinding and biotechnology. J Pharm Pharmacol 2000; 52(3): 253-262.

3. Azaizeh H, Saad B, Khalil K, Said O. The state of the art of traditional Arab herbal medicine in the Eastern region of the Mediterranean: a review. Evidence-based CAM. 2006; 3(2): 229-235.

4. Persidis A. Cancer multidrug resistance. Nat Biotechno. 1999; 17(1): 94-95.

5. Kviecinski MR, Felipe KB, Schoenfelder T, de Lemos $W$ $L P$, Rossi MH, Gonçalez E, Felicio JD, Filho DW, Pedros RC. Study of the antitumor potential of Bidens pilosa (Asteraceae) used in Brazilian folk medicine. $J$ Ethnopharmacol. 2008; 117(1): 69-75.

6. Mohamed A, El-Sayed MA, Hegazy ME, Helaly SE, Esmail AM, Mohamed NS. Chemical constituents and biological activities of Artemisia herba-alba. Rec Nat Prod 2010; 4(1): 1-25.

7. Alzweiri M, Sarhan AA, Mansi K, Hudaib M, Aburjai $T$. Ethnopharmacological survey of medicinal herbs in
Jordan, the Northern Badia region. I Ethnopharmacol 2011; 137(1): 27-35.

8. Aljaiyash $A$, Gonaid $M H$, Islam $M$, Chaouch $A$. Antibacterial and cytotoxic activities of some Libyan medicinal plants. J Nat Prod Plant Resour 2014; 4 (2): 43-51

9. Mandaville J. flora of eastern Saudi Arabia London: Kogan Paul International; 1990.

10. Holmquist G. Hoechst 33258 fluorescent staining of Drosophila chromosomes. Chromosoma 1975; 49(4): 333-356.

11. Tilaoui M, Mouse HA, Jaafari A, Zya A. Comparative Phytochemical Analysis of essential Oils from Different Biological Parts of Artemisia herba alba and Their Cytotoxic Effect on Cancer Cells. PloS one 2015; 10(7): 1-15.

12. Khlifi D, Sghaier RM, Amouri S, Laouini D, Hamdi M, Bouajila J. Composition and anti-oxidant, anti-cancer and anti-inflammatory activities of Artemisia herba-alba, Ruta chalpensis L. and Peganum harmala L.Food Chem Toxicol. 2013; 55: 202-208.

13. Lupidi G, Bramucci M, Quassinti L, Fornari E, Avenali L, Khalife $H$, Gali-Muhtasib HU. Antiproliferative activities of Artemisia herba-alba ethanolic extract in human colon cancer cell line (HCT116). Alternative Medicine Studies. 2011; 1(1): 55-59.

14. Suh Y, Afaq F, Johnson JJ, Mukhtar H. A plant flavonoid fisetin induces apoptosis in colon cancer cells by inhibition of COX2 and Wnt/EGFR/NF-KB-signaling pathways. Carcinogenesis 2009; 30(2): 300-307.

15. Johnstone RW, Ruefli AA, Lowe SW. Apoptosis: a link between cancer genetics and chemotherapy. Cell 2002; 108: 153-164.

16. Gong $F$, Liang $Y$, Xie $P$, Chau F. Information theory applied to chromatographic fingerprint of herbal medicine for quality control. J Chromatogr 2003; 1002: 25-40.

17. Lu KW, Chen JC, Lai TY, Yang JS, Weng SW, Ma YS, Lu PJ, Weng JR, Chueh FS, Wood WG, et al. Gypenosides inhibits migration and invasion of human oral cancer SAS cells through the inhibition of matrix metalloproteinase-2/-9 and urokinase-plasminogen by ERK1/2 and NF-kappa B signaling pathways. Hum Exp Toxicol 2010; 30(5): 406-415.

18. Gong $F$, Liang $Y$, Xie $P$, Chau F. information theory applied to chromatographic fingerprint of herbal medicine for quality control. J Chromatogr 2003; 1002: 25-40.

19. Springfield E, Eagles $P$, Scott G. Quality assessment of South African herbal medicines by means of HPLC fingerprinting. J Ethnopharmacol 2005; 101: 75-83.

20. Bensoussan A, Lee S, Murray C, Bourchier S, van der Kooy, F, Pearson J, Khoo C. Choosing chemical markers for quality assurance of complex herbal medicines: Development and application of the herb MaRS criteria. Clin Pharmacol Ther 2015; 7(6): 628640. 